\title{
ANALISIS AKTIVITAS BELAJAR SISWA PADA PEMBELAJARAN FISIKA MENGGUNAKAN MODEL PROBLEM BASED LEARNING DENGAN PENDEKATAN STEM (Pokok Bahasan Gaya dan Hukum Newton)
}

\author{
${ }^{1)}$ Ainul Kiromah, ${ }^{1)}$ Sudarti, ${ }^{2)}$ Rohatin \\ ${ }^{1)}$ Program Studi Pendidikan Fisika FKIP Universitas Jember, ${ }^{2)}$ SMKN 2 Jember \\ E-mail: ainulkiromah0@gmail.com
}

\begin{abstract}
PBL (Problem Based Learning) learning model with STEM approach can improve student learning activities. Learning activities undertaken are one indicator of students' desire to learn. Student learning activities that occur in the learning process in the form of drawing activities, oral activities, listening activities, and mental activities. The purpose of this study was to determine the effect of Problem Based Learning learning models with the STEM approach to student learning activities. This type of research used was pra-experimental with desain One Shot Case Study. and the sample of this study was students of class X IL2 SMKN 2 Jember.
\end{abstract}

Keywords: PBL learning model with STEM approach, learning activities.

\section{PENDAHULUAN}

Pendidikan merupakan usaha sadar dan terencana yang dilakukan oleh peserta didik untuk mewujudkan suasana belajar dan proses pembelajaran secara aktif agar mengembangkan potensi pada dirinya untuk memiliki spiritual keagamaan, pengendalian diri, kepribadian, kecerdasan, akhlak mulia, serta ketrampilan yang diperlukan dirinya dan masyarakat (Zainuri Arif et al., 2017). Pembelajaran dapat diartikan sebagai upaya guru untuk mengarahkan peserta didik ke dalam proses pembelajaran untuk mencapai suatu tujuan pembelajaran. Oleh karena itu, pembelajaran harus menekankan proses belajar peserta didik dan tugas guru adalah menciptakan sistem lingkungan yang memungkinkan terjadinya proses belajar (Winataputra, 2017). Dengan adanya pembelajaran diharapkan untuk dapat memberikan suatu pemahaman dalam konstektual, serta hal yang utama adalah dapat meningkatkan potensi yang ada pada diri siswa.

Mengembangkan potensi pada siswa dapat dilakukan oleh guru dengan cara menggunakan model pembelajaran yang dapat menjadikan siswa lebih aktif dalam berinteraksi selama proses pembelajaran. Model pembelajaran pada dasarnya merupakan bentuk pembelajaran yang tergambar dari awal sampai akhir yang disajikan secara khas oleh guru. Dengan kata lain, model pembelajaran adalah bungkus atau bingkai dari penerapan atau pendekatan, metode, dan teknik pembelajaran (Nurdyansyah, et al.,2018).

Belajar dibutuhkan adanya aktivitas, dikarenakan tanpa adanya aktivitas proses belajar tidak mungkin berlangsung dengan baik. Pada proses aktivitas pembelajaran harus melibatkan seluruh aspek peserta didik, baik jasmani maupun rohani sehingga perubahan perilakunya dapat berubah dengan cepat, tepat, mudah dan benar, baik 
berkaitan dengan aspek kognitif afektif maupun psikomotor (Hanafiah, 2010:23).

Selama proses pembelajaran berlangsung, penelitian mengamati aktivitas belajar siswa, dan diketahui dari 36 siswa yang terdapat dikelas hanya 7-8 siswa saja yang dapat mengikuti pelajaran dengan baik. Oleh sebab itu, untuk mengatasi permasalahan tersebut, maka peneliti menggunakan model pembelajaran Problem Based Learning dengan pendekatan STEM sebagai alternative untuk meningkatkan aktivitas siswa saat proses pembelajaran.

Model Problem Based Learning (PBL) adalah model mengajar dengan fokus pemecahan masalah yang nyata, proses dimana peserta didik melaksanakan kerja kelompok, umpan balik, diskusi, yang dapat berfungsi sebagai batu loncatan untuk investigasi dan penyelidikan dan laporan akhir. Dengan demikian peserta didik didorong untuk lebih aktif terlibat dalam materi pelajaran dan mengembangkan keterampilan berpikir kritis (Arends, 2008) dalam (Warsono 2017:148-149). Prinsip model pembelajaran Problem Based Learning (PBL) adalah dengan memberikan masalah sebagai langkah awal dalam proses pembelajaran, masalah yang disajikan adalah masalah yang sering dijumpai dalam kehidupan sehari-hari, karena akan semakin baik pengaruhnya pada peningkatan hasil belajar (Amir, 2010:22).

Salah satu cara yang dapat digunakan untuk meningkatkan aktivitas belajar siswa dengan menggunakan model pembelajaran Problem Based Learning adalah pendekatan STEM. Pembelajaran berbasis STEM adalah pembelajaran yang mengintegrasikan keempat disiplin ilmu yaitu, science, technology, engineering, dan mathematic dalam satu kali pembelajaran. Pembelajaran berbasis STEM adalah proses pembelajaran berbasis masalah dan berbasis proyek, karena dalam pembelajaran siswa diberikan masalah untuk diselesaikan dengan menggunakan pemahaman keempat disiplin ilmu STEM kedalam bentuk proyek.

Implementasi STEM dalam pembelajaran bertujuan untuk menjadikan keempat disiplin ilmu (science, technology, engineering, dan mathematic) menjadi pilihan utama bagi siswa untuk menyelesaikan permasalahan serta dapat meningkatkan aktivitas siswa meliputi aktivitas menggambar, aktivitas lisan, aktivitas mendengarkan, dan aktivitas mental.

\section{METODE}

Jenis penelitian yang digunakan adalah penelitian pra-eksperimen tipe deskriptif dengan desain One Shot Case Study (Sugiyono, 2008). Karena tidak ada kelas kontrol, dan hanya ada satu variabel yang ingin dianalisis yaitu aktivitas belajar. One Shot Case Study merupakan eksperimen yang hanya dilakukan pada satu kelompok saja tanpa adanya kelompok pembanding. Penelitian ini bertujuan untuk menganalisis aktivitas belajar siswa SMK melalui model Problem Based Learning (PBL) dengan pendekatan STEM pada pembelajaran fisika materi gaya dan hukum newton.

Penelitian ini dilaksanakan di SMKN 2 Jember. Subyek penelitian ini adalah siswa kelas X IL2 SMKN 2 Jember tahun pelajaran 2019-2020, sedangkan obyek penelitian ini adalah aktivitas belajar. Dalam penelitian ini faktor yang diteliti adalah faktor siswa yaitu melihat peningkatan aktivitas belajar siswa. Teknik yang digunakan adalah teknik purposive sampling yaitu penetapan responden untuk dijadikan sampel berdasarkan kriteria-kriteria tertentu (Siregar, 2013). Jadi, penelitian ini terdiri dari satu kelas eksperimen yang mendapatkan sebuah perlakuan, yaitu diberikan pembelajaran dengan model Problem Based Learning dengan pendekatan STEM (Science, Technology, Engineering, and Mathematics). Dalam penelitian ini, 
pengumpulan data selama proses pembelajaran peneliti menggunakan alat pengumpulan data berupa: (1) Lembar observasi, digunakan untuk mengukur aktivitas siswa. (2) Lembar LKS, digunakan sebagai bahan ajar siswa, dan (3) teknik dokumentasi.

Berikut merupakan tabel desain penelitian

One Shoot Case Study.

\section{$\mathrm{x} \rightarrow \mathrm{O}$}

Desain penelitian One Shot Case Study Keterangan:

$\mathrm{X}$ : Perlakukan yang diberikan kepada siswa yaitu diajarkan dengan menggunakan model Problem Based Learning (PBL) dengan pendekatan STEM.

$\mathrm{O}$ : Aktivitas belajar siswa yang dilihat dari LKS dan Lembar observasi siswa di SMK yang diberi setelah menerapkan model Problem Based Learning (PBL) dengan pendekatan STEM.

(Jaedun, 2011: 10).

Indikator untuk mengukur aktivitas belajar yang diukur melalui indikator aktivitas lisan, aktivitas menggambar, aktivitas mendengarkan, dan aktivitas mental. Lembar observasi tersebut berjumlah 20 item. Klasifikasi aktivitas belajar siswa (tiap individu) dikategorikan dalam klasifikasi tinggi, sedang, dan rendah. Untuk mendapatkan klasifikasi aktivitas belajar siswa digunakan rumus:

\section{Rentang aktivitas belajar $=$ skor maksimal-skor minimal K}

Keterangan: skor maksimal $=80$, skor minimal $=20, \mathrm{~K}$ (jumlah rentang kategori aaktivitas belajar) $=3$. Jadi rentang aktivitas belajar:

$$
\frac{80-20}{3}=20
$$

Sehingga didapat rentang aktivitas belajar dari 3 kategori aktivitas tersebut, yaitu: tinggi (60-80). Sedang (40-59), dan rendah (20-39).

Untuk mengukur presentase perindikator menggunakan rumus:

$$
\% \ln =\frac{\sum I x}{N} \times 100 \%
$$

Keterangan: $\% \ln =$ Presentase indikator $1 / 2 / 3 / 4, \sum I x=$ Jumlah skor max indikator aktivitas 1/2/3/4 x jumlah siswa.

Kemudian untuk mengukur tingkat keberhasilan dari indikator aktivitas menggunakan rumus:

$$
\% A m=\frac{\sum A s}{N} \times 100 \%
$$

Keterangan: $\% A m=$ Presentase siswa beraktivitas tinggi/ sedang/ rendah, $\sum$ As = Banyak siswa yang beraktivitas tinggi/ sedang/ rendah, $\mathrm{N}$ = Banyak siswa yang hadir

\section{HASIL DAN PEMBAHASAN}

Aktivitas belajar dalam penelitian ini diukur melalui lima indikator, yaitu aktivitas menggambar, aktivitas lisan, aktivitas mendengarkan, dan aktivitas mental. Berdasarkan hasil penelitian yang dilakukan, hasil menunjukkan bahwa indikator aktivitas menggambar memiliki presentase 55,5 \%, aktivitas lisan memiliki presentase $66,7 \%$, aktivitas mendengarkan 52,7 \%, dan aktivitas mental memliki presntase $44,4 \%$.

Tabel 1 menyajikan skor klasifikasi aktivitas belajar siswa

\begin{tabular}{|c|c|c|c|}
\hline Indikator & Item & Presentase & Penafsiran \\
\hline $\begin{array}{c}\text { Aktivitas } \\
\text { menggambar }\end{array}$ & $1-5$ & $55,5 \%$ & Tinggi \\
\hline $\begin{array}{c}\text { Aktivitas } \\
\text { Lisan }\end{array}$ & $6-11$ & $66,7 \%$ & Tinggi \\
\hline $\begin{array}{c}\text { Aktivitas } \\
\text { Mendengarkan }\end{array}$ & $\begin{array}{c}12- \\
16\end{array}$ & $52,7 \%$ & Tinggi \\
\hline
\end{tabular}




\begin{tabular}{|c|c|c|c|}
\hline $\begin{array}{c}\text { Aktivitas } \\
\text { Mental }\end{array}$ & $\begin{array}{c}17- \\
20\end{array}$ & $44,4 \%$ & Sedang \\
\hline
\end{tabular}

Hasil penelitian menunjukkan bahwa hasil aktivitas lisan memiliki presentase tertinggi. Hal ini dapat diinterprestasikan bahwa siswa sudah cukup baik dalam melakukan presentasi, khususnya siswa

\section{KESIMPULAN}

Aktivitas belajar siswa setelah diterapkan model pembelajaran Problem Based Learning dengan pendekatan STEM memiliki dampak cukup tinggi. Hal ini artinya model pembalajaran Problem Based Learning dengan pendekatan STEM dapat dijadikan alternative untuk meningkatkan aktivitas belajar siswa pada pembelajaran fisika.

\section{UCAPAN TERIMAKASIH}

Penulis mengucapkan terimakasih kepada semua pihak yang terlibat dalam peneitian ini, terutama kepada bapak Drs. Albertus Djoko Lesmono, M.Si selaku dosen pembimbing lapangan dan ibu Rohatin, S.Pd selaku guru pamong pendidikan fisika SMKN 2 Jember yang telah membantu membimbing sehingga terlaksannya penelitian ini., rekan-rekan fisika yang membatu penelitian ini, serta siswa kelas $\mathrm{X}$ IL2 yang ikut terlibat dalam penelitian ini.

\section{DAFTAR PUSTAKA}

Amir, M. T, (2010). Inovasi Pendidikan melalui Problem Based Learning. Jakarta: Prenada Media Grup

Arends, Richard, 2008. Learning to Teach: Belajar untuk Mengajar. Buku Dua. (Penerjemah: Helly Prayitno Soetjipto dan Sri Mulyantini bertanya mengenai materi yang dijelaskan, serta adanya timbal balik antara siswa dengan siswa dan siswa dengan guru. Oleh sebab itu, penerapan model pembeajarn PBL (Problem Based Learning) dengan pendekatan STEM dirasa cukup baik jika dilakukan pada proses pembelajaran dikarenakan dapat meningkatkan aktivitas belajar siswa dalam beberapa indikator.

Soetjipto). Pustaka Pelajar. Yogyakarta

Gallant, D. J, 2010. Science, Technology, Engineering, and Mathematics (STEM) Education. Retrieved From https://www.mheonline.com/glenc oemath/pdf/stem education.p df.

Hanafiah, Nanang dan Cucu Suhana, 2010. Konsep Strategi Pembelajaran. Bandung: Refika Aditama

Jaedun, Amat. 2011. Metodologi Penelitian Eksperimen. Yogyakarta: LPMP

Jiniarti, Baiq Ewiq, Sahidu dan Verawati. 2015. Implementasi Model Problem Based Learning Berbantuan Alat Peraga untuk Meningkatkan Aktivitas dan Hasil Belajar Fisika Siswa Kelas VIII SMPN 22 Mataram. Jurnal Pendidikan Fisika dan Teknologi. Vol I No 3. Hal: 186-188

Nurdyansyah, Amalia, Fitri, (2018). Model Pembelajaran Berbasis Masalah pada Pelajaran IPA Materi Komponen Ekosistem. Universitas Muhammadiyah Sidoarjo

Siregar, Syofian. 2013. Metode Penelitian Kuantitatif. Jakarta: PT Fajar Interpratama Mandiri

Sugiyono, (2008). Metode Penelitian Kunatitatif Kualitatif dan $R \& D$. Bandung: ALFABETA

Warsono. (2017). Pembelajaran aktif. Bandung: Remaja rosdakarya 